\title{
First records of Falco deiroleucus nest temminck, 1825 (Falconiformes: Falconidae) tree for Brazil and the first description of food storage in hollow tree
}

\author{
Castro, VG. ${ }^{a, b *}$, Castilho, LS. ${ }^{a}$ and D'Fonseca, A. ${ }^{b}$ \\ aBiota Projetos e Consultoria Ambiental Ltda., Rua 86 C, 64, Setor Sul, CEP 74083-360, Goiânia, GO, Brazil

 \\ Minas, MG, Brazil \\ *e-mail: biologovictorcastro@gmail.com
}

Received: May 4, 2014 - Accepted: July 14, 2014 - Distributed: August 31, 2015

The Orange-breasted Falcon (Falco deiroleucus Temminck, 1825) is a bird of the order Falconiformes in the Falconidae family (Menq, 2015). It occurs from Mexico to Argentina and Bolivia, and in almost all regions of Brazil (Sigrist, 2013). The species is considered "Near Threatened" on a global scale (Collar et al., 1992; BirdLife International, 2012). In Brazil, it is in danger of extinction in São Paulo, critically endangered in Ontario and probably extinct in Rio de Janeiro and Rio Grande do Sul (Faria and Kanegae, 2014).

The Orange-breasted Falcon is one of the least known species and perhaps one of the most sparsely distributed in the world. In Brazil, there are no known records about their reproduction (Sick, 2001). Thus, this study describes the first recorded tree nest of $F$. deiroleucus in Brazil and the first description of feeding behaviour using food storage in tree hollows.

A nest was found on December 19 $9^{\text {th }}, 2009$ in Manaus Amazonas/Brazil, in secondary forest impacted by forestry and farming. The nest was in a dead, standing tree, about 30 feet tall. Its cavity had two entrances at about 15 metres above the ground. This nest was photographed by Anselmo D' Fonseca, but there was no monitoring of their activities.

The other nest was located by Victor Castro, in Senator José Porfirio, Pará/Brazil. The region is inserted in the Amazon, but the sampled site is located in an area of pasture, with traces of forest. The nest of $F$. deiroleucus is in a hollow of a dead standing tree, approximately $40 \mathrm{~m}$ high. It is in a large hole in the tree, about 30 metres off the ground. Inside there are two newborn. This nest was monitored for five days, from February $21^{\text {st }}$ to March $3^{\text {rd }} / 2014$, always in the early hours of the day.

The nest cavity is about 1.5 metres high, 1 metre wide, with two side vents. Inside this cavity there are some seedlings, which increase the humidity. Besides this tree nest, the $F$. deiroleucus couple used in the activity another two, from which to watch and feed the chicks, serving as a perch for feeding and resting, observation and starting to hunt prey. These trees were also dead standing trees and were on average 80 metres away from each other.
Regarding the observation of the couple $F$. deiroleucus hunting, caring for and feeding the chicks: early, even in dim light, the male always went hunting and returned carrying in its claws a bat (captured twice) or a bird (captured four times). He handed the prey to the female for eating. When prey was a bird, the female consumed just the head and wings. After withdrawing the feathers and tarsus, she moved through the branches of the tree and deposited the remains inside a small hole in the wood. About an hour later, these remains were with drawn from the hole, and the rest consumed and a portion fed to its young, cutting small pieces of meat and depositing it to the nozzle of each chick.

Two hunting behaviours were performed by the female. First, she attacked a flock of Pionus menstruus Linnaeus 1766 (blue-headed parrot), raising flights to gain altitude and making low-flying and fast flights toward the flock. There were three attempted attacks, but none succeeded. The second was a capture of a Celeus elegans Statius Muller, 1776 (Chestnut Woodpecker), in the forested area. She exhibited the same behaviour when the male gave her food. Thus, both male and female $F$. deiroleucus actively hunt to feed their chicks.

The observations made in this study are relevant to inform the occurrence of the species nests in hollow trees. Also important was the recording of the behaviour of storing food in tree hollows, a behaviour not yet registered for the species. Allied to this, the low number of records in the field and the almost total lack of reproduction in South America, reinforce the importance of more detailed study of this species in order to better understand the behavioural biology of $F$. deiroleucus. Thus, it will be possible to trace steps to prevent this species as being another in the list of threatened fauna.

\section{Acknowledgements}

We thank Biota Projetos e Consultoria Ambiental Ltda. for logistical support for data collection and Iubatã Paula Faria for the theoretical support and encouragement. 


\section{References}

BirdLife International, 2012. Falco deiroleucus. The IUCN Red List of Threatened Species. Cambridge: IUCN. Available from: $<$ http://www.iucnredlist.org/details/22696516/0>. Access in: 18 Apr. 2014.

COLLAR, NJ., GONZAGA, LP., KRABBE, N., MADROÑONIETO, A., NARANJO, LG., PARKER-III, TA. and WEGE, DC., 1992. Threatened birds of the Americas: The ICBP/IUCN Red Data Book. 3rd ed, Cambridge: International Council for Bird Preservation. 1150 p. part 2.
FARIA, IP. and KANEGAE, MF., 2014. Ocorrência de Falco deiroleucus na Mata Atlântica de Minas Gerais, Brasil. Atualidades Ornitológicas, no. 177. Available from: <http://www.ao.com.br/ ao177.htm>. Access in: 17 Apr. 2014.

MENQ, W., 2015. Aves de Rapina Brasil: Orange-breasted Falcon . Available from: $<$ http://www.avesderapinabrasil.com $>$. Access in: 15 Apr. 2014.

SICK, H., 2001. Ornitologia Brasileira. Rio de Janeiro: Nova Fronteira. p. 264-265.

SIGRIST, T., 2013. Guia de campo Avis Brasilis: Avifauna Brasileira. São Paulo: AvisBrasilis. 200 p. 